\title{
Perceived Organizational Support, $O C B$ and Creative Behaviour among Millennial Generation Start-up Employees
}

\author{
Erika Setyanti Kusumaputri \\ Program Studi Psikologi \\ Fakultas IImu Sosial dan Humaniora \\ UIN Sunan Kalijaga \\ erika.kusumaputri@uin-suka.ac.id
}

\author{
Sitta Puteri Kumalasari \\ P.T Pameo Solusi \\ Indonesia \\ sitta.pameo@gmail.com
}

\author{
Sabiqotul Husna \\ Program Studi Psikologi \\ Fakultas IImu Sosial dan Humaniora \\ UIN Sunan Kalijaga \\ sabiqotul.husna@uin-suka.ac.id
}

\begin{abstract}
Millennial generation employees were expected to have the ability to create and innovate. This ability will lead to creative behaviour particularly when companies support employee welfare which was strengthened by organizational citizenship behaviour (OCB). The purpose of this study was to investigate the relationship between organizational citizenship behaviour as a mediator of perceived organizational support (POS) for creative behaviour. The number of research participants was 157 millennial generation employees from Indonesian start-up companies. Data were collected using the creative behaviour scale $(\alpha=0.887)$, the POS scale $(\alpha=0.945)$, and the OCB scale $(\alpha=0.95 \mathrm{I})$. The results of the study based on the path analysis method showed that the indirect effect had a coefficient of $0.339(p<0.05)$, which means that there was a positive relationship between POS and creative behaviour through OCB. The positive sign on the correlation coefficient showed the direction of a positive relationship, which means that the higher the POS employees have, the higher the employee's creative behaviour through OCB. $O C B$ as a mediator contributed $46.4 \%$ to POS towards creative behaviour.
\end{abstract}

Keywords: millennial generation, organizational citizenship behaviour, perceived organizational support, creative behaviour

Received 8 February 202I/Accepted 9 June 202I @Author all rights reserved

\section{Introduction}

In 2020, the working world in Indonesia was dominated by millennial generation. This means that baby boomers and generation $X$ experienced a decline in population within the work field. Millennial who are about to enter the working world begin to face various kinds of challenges,

including being able to meet labour market demands and having the creativity to be able to compete and maintain their careers. Lancaster and Stillman (2003) explained the categorization of generations, millennial generation is a term used for those who were born after $198 \mathrm{I}$ to 
1999 and are currently starting to enter the working work. This generation is also referred to as "Generation Y".

The population of Indonesian millennial generation in 2013 , based on data from the Central Bureau of Statistics, was recorded approximately 83 million people. It means that there were about 33\% from total population of Indonesian citizen. In 2016, the total workforce in Indonesia reached around 160 million people divided into three generations, namely the baby boomers generation, the $X$ generation and the millennial generation (Alvara Research Center, 2017; BPS, 2016; Dale Carnagie Indonesia, 2016).

In this millennial era, companies do not only rely on the strength of natural resources to survive, but also human resources are very important to be relied on. It is mainly because companies need ideas that are not only capable of helping economic growth, but also helping companies win the competition ahead. The source of economic power in the millennial era has also undergone a change, which initially came from current natural resources and now changes into creativity or new ideas (Myers \& Sadaghiani., 2010; Clarke \& Clegg., 2000; Biggs, Westley, \& Carpenter, 2010).

The millennial era was shown by the trend in Indonesia where many companies started their business through the development of simple ideas. One thing that can be seen is that the startup industry in Indonesia has been starting to grow. Start-up is an industry related to the world of technology and social networks, and requires creativity (Eaggers, Lovelace, \& Kraft., 2017). Some of the well-known start-ups in Indonesia include Go-Jek, Traveloka, and Bukalapak. These three start-up companies were founded by three people from the millennial generation with different ideas background (Ali and Purwandi, 20I7).

The large number of start-up growth that has emerged in Indonesia can be described as a positive trend, because more job opportunities are developed and available. Armed with creativity and innovation as well as better technology than previous generations, the millennial 
generation is expected to create jobs. Most of the businesses being developed are certainly not far from the digital industry, particularly the start-up industry (https://www.inews.id/finance/ makro).

Rice (2006) stated that creative behaviour is employees' perceptions and beliefs about their creativity in producing new and useful products, ideas and procedures. According to Oldham \& Cummings (1996), indicators of creative behaviour were I) individuals are happy with activities in their work and are interested in being involved for the activities within it, 2) individuals tend to take risks to explore new ideas and play with ideas and the new materials, 3 ) individuals tend to stay focused on the internal nature of the task, 4) individuals tend to work longer hours on an idea or a problem, 5) individuals tend to complete work without external control and obstacles.

In several studies, it was explained that creativity possessed by employees in an organization can help to improve organization performance (Ghosh, 2014; Riaz \& Hassan, 2019). Creativity is also a crucial element for organizations that want to innovate because creativity is the foundation for organizations to be able to innovate (Riaz \& Hassan, 2019). Organizations that are ready to innovate through new ideas resulting from the creative process will be able to survive in the face of a very dynamic business world (Amabile, 1997; Amabile et al., 1996; Klijn \& Tomic, 2010).

The need for creativity among Indonesian start-up employees is strengthened by Indonesia's current position compared to China and South Korea, which is still quite far from the development stage (I0 Dec. 20, https://industri.kontan.co.id/news/ini-alasan-start -upIndonesian-lose-with-foreign). It was explained that according to the Deputy for Access to Capital of Creative Economy Agency, Fadjar Hutomo, the problem was the capability of startup entrepreneurs. Capability in the industrial sector was shown by creativity (Ferreira, Coelho, \& Moutinho, 2018). In other words, creativity of start-up employees in Indonesia is still lacking compared to other countries in Southeast Asia. 
Employee creativity can be shaped and improved in a creative organizational environment, thus it can bring out the creativity of employees within the organization (Ibrahim, Isa \& Shahbudin, 2016; Yulianti, 2014). However, in reality, some organizations do not provide support to their employees in generating creativity (Madjar, Oldham, \& Pratt., 2002; McLean, 2005).

Amabile, et al (1996) revealed that the social environment can influence creative behaviour. Other studies explained that the organizational climate also has a significant influence in terms of stimulating employee creative behaviour (Moghimi \& Subramaniam, 2013). Employee creativity will emerge if the organization confirms that creativity is a valuable thing for the organization, and then communicates these values as well as forms a culture that strengthens the values of managed creativity management (McLean, 2005; Choi et al., 2010; Ibrahim et al., 2015). It shows the importance of perceived organizational support (POS) received by employees.

Rhoades and Eisenberger (2002) described that perceived organizational support is employees' belief that the contribution they made to the organization was valued positively by the organization with the concern shown by the organization for the welfare of their employees. Perceived organizational support has several indicators including: I) contributions that are appreciated by the organization, 2) extra effort that is appreciated by the organization, 3) attention to employee complaints, 4) organizational concern for the welfare of employees, 5) organizational feedback on the completed work that was not done correctly, 6) organizational concern for employee satisfaction, 7) attitudes of concern shown by the organization towards employees, 8) organizational pride for employee success (Rhoades \& Eisenberger, 2002).

The belief in the perception of organizational support particularly when the employees believe their organization supports them, can also increase voluntary citizenship behaviour based on the underlying social exchange theory. It was developed from trust and goodwill between the two parties (Eisenberger et al., 1986; Rhoades \& Eisenberger, 2002; Yoon \& Suh, 2004). Employees who demonstrated organizational citizenship behaviour will poses a sense that they 
are part of their organization and will voluntarily share needed knowledge with their colleagues. This voluntary social behaviour will influence employees in showing their creative behaviour. It was described by Perry-Smith and Shalley (2003) that the potential for creativity can be increased through interaction with other people and exchanging the ideas itself.

In their book, Organ, Podsakoff, \& Mackenzie (2006) described that organizational citizenship behaviour is an extra performance shown by employees as pro social behaviour with the intention of helping to improve the overall quality of the organization without any formal appreciation from the organization. There are seven aspects of organizational citizenship behaviour, namely: I) helping behaviour, 2) sportsmanship, 3) organizational loyalty, 4) organizational compliance, 5) individual initiative, 6) civic virtue, and 7) self-development.

The findings from Jebeli and Etebarian study (2015) revealed similar conclusion, that the high perception of employees towards organizational support can also increase employee organizational citizenship behaviour and vice versa. Other studies also showed identical results that the higher the support provided by organizations to their employees, the better the employee's organizational citizenship behaviour will be. This confirms the statement of Rhoades and Eisenberger (2002) which stated that employees who received more support from the company will be more responsible for their work, help their colleagues and provide useful ideas. Another previous study by lbrahim et al. (2015) also described perceived organizational support has a significant relationship with employee creativity. In addition, Akturan and Cekmecelioglu (2016) revealed through their study that organizational citizenship behaviour has a positive effect on employee creative behaviour.

Based on several previous studies explained before, it has been concluded that it is still necessary to execute further research on creative behaviour by involving psychological variables (Klijn \& Tomic, 2008) including perceived organizational support and organizational citizenship behaviour, with OCB as the mediator.Some of the gaps from the previous research were; first, on the organizational citizenship behavior variable, the majority of research used five old 
general dimensions, namely altruism, conscientiousness, sportsmanship, courtesy, and civic virtue, (Ocampo, dkk., 2017) while this presented study used seven aspects of organizational citizenship behavior derived from 30 potential dimensions of OCB which were developed in accordance with the conditions of the century of 20th. Furthermore, these dimensions were divided into seven aspects, namely helping behavior, sportsmanship, organizational loyalty, organizational compliance, individual initiative, civic virtue, and self-development (Podsakoff, MacKenzie, Paine, \& Bachrach., 2000; Ocampo, et al., 2018); Secondly, the majority of the population in the previous studies has the same characteristics, namely personnel from educational institutions and hotels within certain region (de Geus, et all 2020), thus the generalizability of the research was limited, particularly among millennial employees in start-up companies.

Result of this presented study was expected to be fruitful and beneficial for study that in this millennial era companies cannot only rely on the strength of natural resources, but also need to rely on the human resources with their creativity. Human resource and its creativity are certainly important to enhance company performance and stimulate innovation.

\section{Method}

\section{Respondent}

The research subject in this study was 157 start-up employees who live in the province of D.I Yogyakarta, DKI Jakarta, and West Java. The age of the respondents was in the category of millennial generation, approximately between 20-36 years old. The measurement instrument used in this study was the creative behaviour scale, the perceived organizational support scale, and the organizational citizenship behaviour scale, which were respectively constructed and developed by researchers. Completion of the survey emphasized on the willingness of the subjects, firstly informed consent was firstly given as an introduction of questionnaire. The subjects were also well-informed that there is no pressure to fill out the questionnaire. After 
the subject agreed and filled out the informed consent sheet, then they completed the questionnaire.

\section{Measurement}

The creative behaviour scale revealed employees' perceptions and beliefs about their creativity in producing new and useful products, ideas and procedures (Rice, 2006). Indicators of creative behaviour were developed based on theory from Oldham \& Cummings (1996), namely; individuals are happy and interested in activities in their work, tend to be brave to explore new ideas, focus on the internal nature of tasks, work longer on an idea, are able to complete their work without external obstacles. Item validity used Aiken $\mathrm{V}$ calculation, which was on the range of 0.5-0.75. The reliability of the measurement used the Cronbach's Alpha coefficient technique. The result of the reliability coefficient was 0.887 . The total number of items was 29 . An example item was "I easily take risks to explore new ideas", "I easily take risks to explore new ideas", "Risk is not an obstacle to exploring new ideas".

The perceived organizational support scale revealed members' ratings of organizational rewards for contributions they made. Organizational awards for members are in the form of concern for the welfare of members (Rhoades \& Eisenberger, 2002). This scale measured the contribution valued by the organization, the extra effort that the organization appreciates, attention to its members, organizational concern for the welfare of its members, organizational feedback on member works, organizational concern for member satisfaction, attentiveness shown by the organization, and organizational pride for success its members. Item validity used Aiken $V$ calculation, which was in the range between 0.5-0.75. The reliability of the measurement used Cronbach's Alpha coefficient technique. The result of the reliability coefficient was 0.945 . The total number of items was $3 \mathrm{I}$. An example of an item in this scale was "The company gives more rewards for my extra effort"."The company appreciates the effort I have and I put on", "The company conducts periodic evaluations of my performance". 
Organizational citizenship behaviour scale revealed extra performance shown by members as pro social behaviour, the goal was to help improving the overall quality of the organization, without expecting formal appreciation from the organization (Organ, Podsakoff \& Mackenzie, 2006). Aspects of scale were helping behaviour, sportsmanship, organizational loyalty, organizational compliance, individual initiative, civic virtue, and self-development ( selfdevelopment). Item validity used Aiken $\mathrm{V}$ calculation, which was in the range between 0.5-0.75. The reliability of the measurement used the Cronbach's Alpha coefficient technique. The result of the reliability coefficient was 0,951 . The total number of items was 53. Example of item in this scale was "I help colleagues voluntarily"."I help to prevent problems voluntarily", "I can afford to put in more effort to get the job done"

\section{Design}

This presented research used correlational quantitative in perceived organizational support, OCB and creative behavior.

\section{Data Analysis}

The data analysis method used in this study was statistical techniques, path analysis withthe assumption test approach and hypothesis testing. The assumption test was done as a prerequisite before the hypothesis test is carried out, which was by performing the normality test, linearity test, heteroscedasticity test and multicollinearity test. The measurementwas executed using the 22.0 version of SPSS software application.

\section{Result}

In this study, researchers carried out several stages of research, namely I). Performing the assumption test of multi co-linearity test, heterosedacity test, normality residual test, and linearity test, 2) Testing the factors that predict creative behaviour, namely POS and OCB using path analysis, 3). Calculating the descriptive statistics for creative behaviour variables POS and $\mathrm{OCB}, 4)$. Calculating the subject score categorization. 


\section{Assumption Test}

The results of the multi co-linearity test assumption were described below:

\section{a. Dependent Variable: Creative Behavior}

Based on co-linearity statistics result, it was found that there was no tolerance value below 0.10 , none of the VIF values were above 10. It shows that the range between Tolerance and VIF was narrow with VIF was I.5I3. Hence it can be concluded that multi co-linearity does not occur between independent variables because it has a tolerance value greater than 0.10 and a VIF value less than 10 .

From heteroscedasticity test, the result showed that perceived organizational support and organizational citizenship behavior has a significance value of 1,000 . According to Ghozali (2016), the requirement for no heteroscedasticity to occur is if the significance value ( $p$ ) is greater than 0.05 . Thus, it can be concluded that the significance value of all independent variables was more than 0.05 , which means that there was no heteroscedasticity in this regression model and it has the same / homogeneous distribution of variants.

Based on the normality residual test, it was found that the Kolmogorov-Smirnov value was 0.33 with a significance level of 0.200 which was far above 0.05 . The result of the significance level (P) showed more than 0.05 , which means that the residuals were normally distributed, and the statistical test was valid on the sample.

Linearity test used the Compare Means function. The result showed the significance value of perceived organizational support data on organizational citizenship behavior was 0,000 indicating linear data $(\mathrm{p}<0.05)$. Furthermore, data on organizational citizenship behavior on creative behavior has a significance value of 0.000 indicating linear data $(p<0.05)$. Perceived organizational support data for creative behavior also shows a significance value of 0.000 indicating linear data $(\mathrm{p}<0.05)$. 
Test of Predictors for Creative Behavior

The testing process for factors that predicted creative behavior, namely POS and OCB was executed using path analysis. Tables I, 2 and 3 explained the results of statistical calculations.

Table I

Direct Effect Regression Coefficient

\begin{tabular}{clll}
\hline Path & \multicolumn{1}{c}{ Independent Variables } & \multicolumn{1}{c}{ Dependent Variable } & $\begin{array}{c}\text { Direct } \\
\text { effect }\end{array}$ \\
\hline Pl & Perceived Organizational Support & Creative Behavior & 0.125 \\
\hline p2 & Perceived Organizational Support & $\begin{array}{l}\text { Organizational Citizenship } \\
\text { Behavior }\end{array}$ & 0.909 \\
\hline p3 & Organizational Citizenship Behavior & Creative Behavior & 0.374
\end{tabular}

In the path analysis model, the direct effect was shown by the path values pl, p2 and p3. The path coefficient value was obtained from the regression beta coefficient. The results of regression analysis of the direct effect of research data in table 5 shows that independent variable POS on the dependent variable has a direct influence with $\beta=0.125$. POS as an independent variable has a direct effect on $\mathrm{OCB}$ as the dependent variable with $\beta=0.909$. Furthermore, the independent variable OCB to the dependent variable creative behavior has a direct effect with $\beta=0.374$.

Table 2

Indirect Effect of Regression Coefficient

\begin{tabular}{llcl}
\hline \multicolumn{1}{c}{ Independent Variable } & $\begin{array}{c}\text { Dependent } \\
\text { Variable }\end{array}$ & Mediator Variable & Indirect Effect \\
\hline $\begin{array}{l}\text { Perceived Organizational } \\
\text { Support }\end{array}$ & $\begin{array}{l}\text { Creative } \\
\text { Behavior }\end{array}$ & $\begin{array}{c}\text { Organizational } \\
\text { Citizenship Behavior }\end{array}$ & $\begin{array}{l}(\mathrm{p} 2) 0,909 \times(\mathrm{p} 3) 0,374 \\
=0,339\end{array}$ \\
\hline
\end{tabular}

The indirect effect analyzes the role of independent variable on dependent variable which was strengthened by the mediator variable (Ghozali, 2016). The mediator variable in this study was 
OCB. The results of indirect regression analysis (table 2) shows that POS as an independent variable have indirect effect on creative behavior as a dependent variable through the $O C B$ as mediator variable which was obtained from the multiplication of $\beta$ between p2 and p3 $(0.909 x$ 0.374) thus the coefficient results were 0.339 . To test the role of the OCB variable in mediating POS on PK, the Sobel Test was used with the following formula.

$$
\begin{aligned}
& z=\frac{a b}{\sqrt{\left(b^{2} S E_{a}^{2}\right)+\left(a^{2} S E_{b}^{2}\right)}} \\
& z=\frac{0.909 \times 0.374}{\sqrt{\left(0.374^{2} 0.102^{2}\right)+\left(0.909^{2} 0.038^{2}\right)}} \\
& z=\frac{0.3399}{\sqrt{0.0026}} \\
& z=\frac{0.3399}{0.0509} \\
& z=6.6777
\end{aligned}
$$

Based on the result of the Sobel Test calculation above, the $z$ value was obtained of 6.6777 . It proves that OCB was able to mediate the effect of POS on Creative Behavior, because the $z$ value obtained was $6.6777>1.96$ with a significance level of $5 \%$.

Table 3

Pearson Correlation Hypothesis Test Results

\begin{tabular}{clccc}
\hline & & POS & OCB & $\begin{array}{c}\text { Creative } \\
\text { behavior }\end{array}$ \\
\hline POS & Pearson Correlation & 1 & $.582^{* *}$ & $.522^{* *}$ \\
& Sig. (I-tailed) & & .000 & .000 \\
& $\mathrm{~N}$ & 157 & 157 & 157 \\
OCB & Pearson Correlation & $.582^{* *}$ & 1 & $.738^{* *}$ \\
& Sig. (I-tailed) & .000 & & .000 \\
& $\mathrm{~N}$ & 157 & 157 & 157 \\
\multirow{5}{*}{ Creative } & Pearson Correlation & $.522^{* *}$ & $.738^{* *}$ & 1 \\
behavior & Sig. (I-tailed) & .000 & .000 & \\
& $\mathrm{~N}$ & 157 & 157 & 157 \\
\hline
\end{tabular}


Table 3 illustrates the total correlation, which was the sum of the direct influence of POS on creative behavior $(\mathrm{Pl})$ and the indirect effect of POS on creative behavior through OCB ( $2 x$ p3) which was calculated as follows:

Total effect value $=p I+(p 2 \times p 3)$

$$
\begin{aligned}
& =0.125+0.339 \\
& =0.464
\end{aligned}
$$

From these results it can be concluded that the effect of mediator variable was $46.4 \%$. Meanwhile, the influence of other variables that cannot be explained by the independent variable POS on creative behavior was $53.6 \%$.

Moreover, based on the results analysis in table 3, it can be seen that there was a significant relationship between perceived organizational support and creative behavior with a correlation coefficient of rxy 0.522 ( $p$ <0.05). Furthermore, there was a significant relationship between perceived organizational support and organizational citizenship behavior with an rxy value of 0.582 ( $p$ <0.05). In addition, there was a significant relationship between organizational citizenship behavior and creative behavior with a rxy value of $0.738(p<0.05)$. Based on the results of this analysis, the mediator variable played a role in strengthening the POS variable with creative behavior.

Empirically, the test results show the correlation between POS variables and Creative Behavior through OCB mediators. The results of the path analysis can be seen in Figure I, below. 
Figure I. The Path Analysis Model

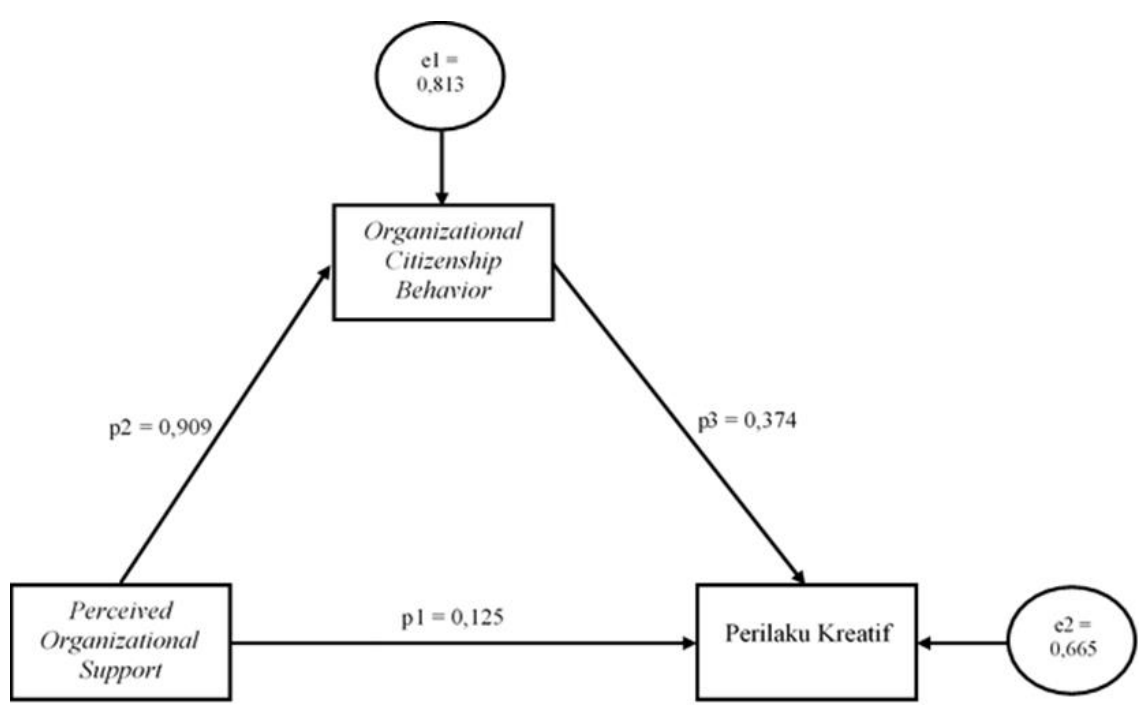

Subject Score Categorization

Based on the data collection process, 157 respondents who participated were millennial employees of start-up companies located in DIY, DKI Jakarta and West Java. The characteristic of a start-up is a company that is specifically developed in Indonesia, and has not yet entered the unicorn category. There were 45 start-up companies involved in the research.

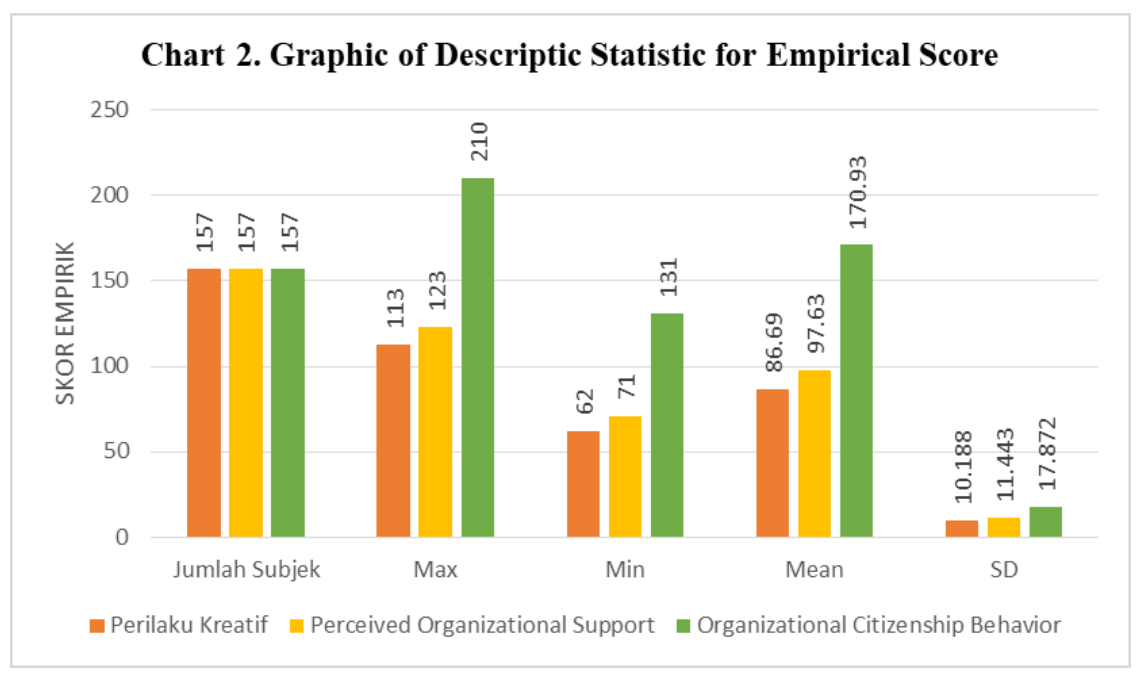


The score calculation shows that there were no subjects who were in very low and low categories. The subject categories were described in Chart 3 below, indicating that the levels of creative behavior, POS and OCB were mostly high.

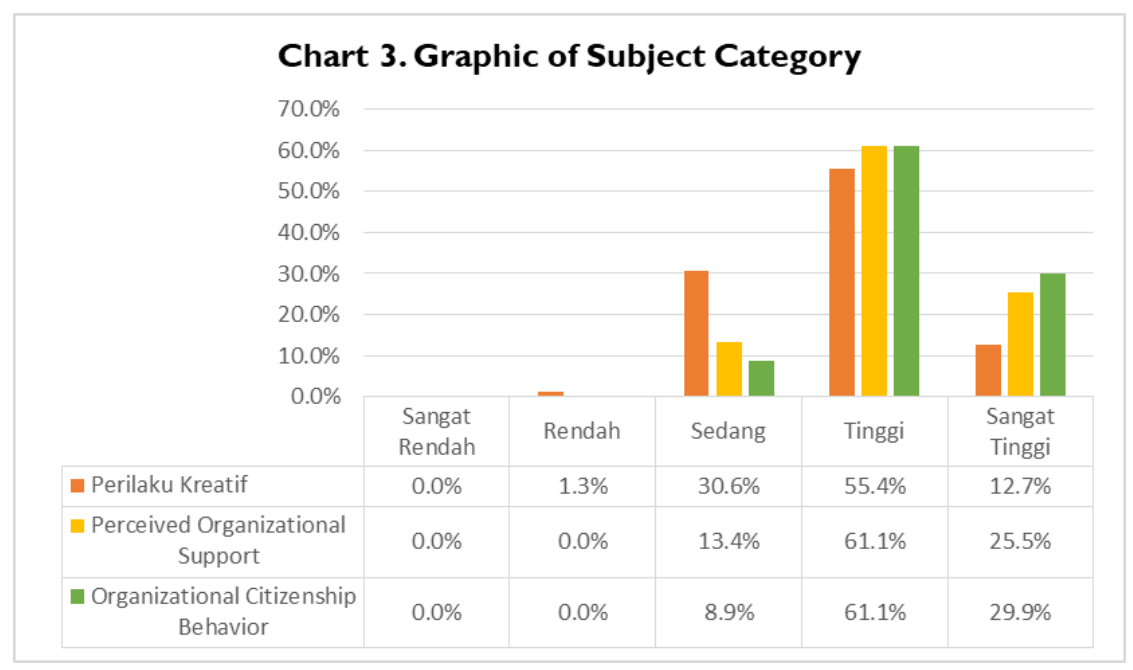

\section{Discussion}

The result of research on employees of start-up companies in the Province of D.I. Yogyakarta, DKI Jakarta, and West Java showed there was a positive relationship between perceived organizational support and creative behavior through organizational citizenship behavior, which means that the first hypothesis in this study was accepted. In addition, the result of the direct effect of perceived organizational support on creative behavior was also significant. It means that the second hypothesis in this study which stated that there is a positive relationship between perceived organizational support and creative behavior was accepted.

The hypothesis that showed a positive relationship between perceived organizational support and organizational citizenship behavior on creative behavior was proven to be significant. In addition, there was also significant result on the variable perceived organizational support for 
organizational citizenship behavior. This result means that the three variables have a significant correlation thus the conditions for using the mediator variable were fulfilled.

The total effect involving the role of organizational citizenship behavior, was greater than the number of direct effects of perceived organizational support on creative behavior without mediated organizational citizenship behavior. It means that perceived organizational support and organizational citizenship behavior were quite influential on increasing creative behavior. Therefore, result of this study indicated that the higher / better the perceived organizational support of millennial generation employees in start-up companies, the higher creative behavior through organizational citizenship behavior will be. Conversely, the lower / worse perceived organizational support that millennial generation employees have in start-up companies, it will reduce employee creative behavior. Hence it can be argued that high perceived organizational support accompanied by high organizational citizenship behavior in millennial generation employees in start-up companies was able to increase employee creative behavior.

Perceived organizational support that employees have has a big role in increasing employee creativity because with this creativity organizational performance and productivity will increase because employees will feel motivated (Ibrahim et al., 20I5; Kahn, 1992). Oldham and Cummings (1996) stated that one form of organizational supports is the role of supervision that is able to provide support to its employees. Supervision that supported employees has been believed will increase employee creative achievement. However, if supervision is too controlling and limits the activities of employees in completing their tasks, it will lower employee creativity.

Other findings also added that organizational support and creativity were the extent to which an employee perceived these two things. If the organization is able to emphasize that creativity is a valuable thing for the organization, and is able to communicate these values then it forms a culture that strengthens the values of managed creativity management (Ibrahim et al., 20I5; Choi, et al., 2010). 
Employees who belief in the perception of organizational support that they are supported by the organization at work can increase voluntary civic behavior, because of the underlying social exchange theory which was founded on trust and goodwill built between the two parties (Eisenberger et al., 1986; Rhoades \& Eisenberger, 2002; Yoon \& Suh, 2004). Employees who demonstrated organizational citizenship behavior will feel they are part of their organization and will share needed knowledge with their colleagues voluntarily. The influence of this social behavior will show the creative behavior of employees. It was described by Perry-Smith and Shalley (2003) that interaction with other people accompanied by an exchange of ideas can increase the potential for employee creativity.

Jebeli and Etebarian (2015) explained that the high perception of employees towards organizational support can also increase employee organizational citizenship behavior, and vice versa. In other words, it can be argued if the organization provides high support for employee creativity, it can direct their attention in generating new ideas and ways of doing things to adapt and improve results. Employees who receive more support from the company will be more responsible for their work, helping their colleagues and providing useful ideas.

Through indicators of organizational valued that contribution from perceived organizational support, organizational citizenship behavior owned by employees is increases the aspects of helpful behavior and sportsmanship. The reason was employees who voluntarily provided assistance to prevent work-related problems will be considered as employee contributions to the organization they work for. In addition, sportsmanship shown through being willing to sacrifice their personal interests for the benefit of the group is also considered a form of employee contribution to the organization.

The organizational citizenship behavior aspects for instance helping voluntarily, promoting organizations to other parties, willing to take extra responsibility, surviving with extra enthusiasm and effort to complete a job can increase organizational citizenship behavior with an indicator of extra effort valued by organizations from perceived organizational support. 
Rewards for this extra effort can appear in the form of promotions and salary increases. The wise citizen aspects can also be improved through the complaint indicator, which means the extent to which the organization pays attention to complaints raised by employees, including hearing and considering suggestions and input from employees.

The indicators of how organization care about the welfare of its employees from perceived organizational support can increase aspects of organizational loyalty and self-development. Organizations that show concern by providing adequate equipment for employees' work and providing job insurance for them will eventually make employees maintain and defend the organization from external threats, and remain committed to the organization even under adverse conditions. In addition, organizations that provide training for employees for the sake of their work continuity can also increase organizational citizenship behavior, because employees can seek and take advantage of training or learn new skills that can expand the range of contributions to the organization.

The next aspect of organizational citizenship behavior is organizational fulfillment. This aspect can be improved through organizational indicators that inform employees if work is not executed well because employees make mistakes while working because they are not in accordance with operational standards and procedures, it will be given a proper direction. It makes employees fulfill the internalization, accept and understand organizational procedures that will result in compliance with employees. Furthermore, the indicator on how organization care about employee satisfaction are also able to increase organizational citizenship behavior through several aspects, namely loyalty to the organization and wise citizens. With regular attention and evaluation from the organization, employees will remain committed to the organization even though they are in adverse conditions, which will lead to greater interest in the commitment of the organization as a whole. It is indicated by the willingness of employees to actively participate in organizational activities. 
The description above explained that perceived organizational support can increase organizational citizenship behavior. From the result analysis in this study it was found that perceived organizational support provided an effective contribution of $33.9 \%$ to organizational citizenship behavior. Thus perceived organizational support was related to organizational citizenship behavior which means that by increasing organizational citizenship behavior, creative behavior will also be higher.

Based on the path analysis result, it showed that organizational citizenship behavior provided an effective contribution of $55.7 \%$ to creative behavior. Organizational citizenship behavior has an important role as an intermediary for the relationship of perceived organizational support to creative behavior which can be understood based on the findings of Akturan and Cekmecelioglu (2016) research that organizational citizenship behavior affected the creative behavior of employees in organizations in creative ways. In addition, employees who felt that they are part of an organization and the organization itself can provide the information they need were also able to make employees more creative.

Indicators of creative behavior consist of individuals who are happy with activities in their own work and are interested in being involved for the activities that are in it, individuals tend to take risks to explore new ideas and play with these new ideas and materials, individuals tend to stay focused on the internal nature of the task, individuals tend to work longer on an idea or a problem, and in completing a job, individuals tend to complete it without external control and obstacles. Meanwhile, aspects of organizational citizenship behavior include: helping behavior, sportsmanship, organizational loyalty, organizational compliance, individual initiative, civic virtue, and self-development.

Helping behavior is one of organizational citizenship behavior aspects. When helping behavior occurs in the work environment by involving helping others voluntary hence work-related problems can be prevented. It is believed will increase employee creative behavior because employees tend to complete their work without any obstacles. In addition, sportsmanship in 
organizational citizenship behavior such as not showing complaints when employees feel uncomfortable with others, maintaining a positive attitude even though something does not go as expected, not being offended when others follow other suggestions and not rejecting other people ideas privately, and being willing to sacrifice their personal desires for the good of the group can also enhance employee creative behavior.

Employees who showed such sportsmanship will keep employees focused on the internal nature of their duties. Employees will not be easily distracted by things that are external, because they will be more focused on completing their work. It is consistent with one of the characteristics of millennial generation employees who enjoy working in groups because they also show a more tolerant nature.

Loyalty to the organization shown by employees where they work through the organization promotion to external party, guarding and defending the organization from external threats, and remaining committed to the organization even in adverse conditions, it is thought that their creative behavior can also increase. It was supported by evidence from one of the creative behavior indicators that employees will tend to take risks to explore new ideas, even when they are in a detrimental state.

Creative behavior that can be seen from other aspects of organizational citizenship behavior, namely the existence of initiative actions that are owned by employees by engaging in behaviors related to completing tasks that are at a higher level of difficulty than their abilities. These actions were designed to improve a task or organizational performance, survive with the extra zeal and effort to complete a job, be willing to take extra responsibilities, and encourage others in the organization to do the same. This initiative of employees also increased their indicators of creative behavior because employees tend to work longer on an idea or problem and stay focused on the internal nature of the task. In addition, three characteristics of millennial generation employees also emerged, namely having the ability to create and innovate, 
accustomed to make their own decisions and willing to spend extra effort for organizational success.

In a company, employees should also be wise citizens or be interpreted as civic virtues. Civic virtue represents an interest in a greater overall organizational commitment which is demonstrated by a willingness to actively participate in organizational activities for instance attending meetings and giving opinions. It was done to monitor the organization's environment from threats and opportunities that could appear from outside the organization. It is believed that civic virtue behavior can increase indicators of creative behavior because employees feel happy with the activities they do in their work and are interested in being directly involved for the activities in it.

The last aspect of organizational citizenship behavior is self-development which is voluntary behavior carried out by employees to increase their knowledge, skills and abilities by seeking and taking advantage of training, keeping abreast of the latest developments in a field and area, or even learning a new skill to expand the range of contributions to the organization. Employees who develop themselves by following training will tend to find it easier to further explore their ideas without fear of the risks. In addition, the aspect of self-development is also one of the characteristics of millennial generation employees who are aware of the importance of training to support their career paths, hence it can lead to creative behavior in employees.

Based on the explanation above, it can be concluded that the importance of organizational citizenship behavior as a mediator of perceived organizational support for creative behavior is to make individuals happier and involved in their work activities, be able to take risks to explore new ideas, be able to focus on tasks, be able to work more long time on an idea, and be able to complete the job without any external obstacles. It proved that an individual has high creative behavior (Akturan \& Cekmecelioglu, 2016). 
The organization has a role in monitoring employee performance to comply with the company's operational standards. If something goes wrong, then the organization, through supervision, must provide proper direction to employees. In turn, it stimulated the creative behavior of employees in completing a job, because employees will tend to complete the job without external interference. One of the characteristics of millennial generation employees is evident in this model, namely millennial generation employees need guidance from ongoing supervision in their work.

Employee creativity in the organization can also be raised through a creative organizational environment (Ibrahim, Isa and Shahbudin, 2016; Yulianti, 20I4). Amabile (1996) also revealed that the social environment can influence creative behavior. Not only that, employee creative behavior can also be stimulated by a significant influence through the climate in an organization (Moghimi \& Subramaniam, 20I3).

The sum of total effect of perceived organizational support involving organizational citizenship behavior was $46.4 \%$, besides that there were still $53.6 \%$ other variables that cannot be explained by the variable perceived organizational support and organizational citizenship behavior on creative behavior. It was one of the shortcomings of this study because organizational citizenship behavior does not fully mediate the relationship between the two variables and it was found that there were still other variables that influence creative behavior besides perceived organizational support and organizational citizenship behavior namely employee personality, job meaning, organizational commitment, workload, and leadership.

Based on the category of subject's creative behavior score, it can be concluded that millennial generation employees who worked at start-up companies in D.I. Yogyakarta, DKI Jakarta and West Java were in high category. It showed that millennial generation employees who worked in start-up companies in three provinces have good creative behavior. Furthermore, millennial generation employees who were in the medium category, while millennial generation employees within very high category. However, there were 2 people of millennial generation 
employees who have low category creative behavior that needs to be a concern for companies to improve their creative behavior.

Judging from the categorization of perceived organizational support scores, millennial generation employees who worked in start-up companies in D.I. Yogyakarta, DKI Jakarta and West Java have high perceived organizational values. Thus, it can be concluded that most of the millennial generation employees at start-up companies in D.I. Yogyakarta, DKI Jakarta and West Java have high categories of perceived organizational support. This is quite a concern hence it can be maintained and improved to avoid a decline trend into low category.

Moreover, judging by the subject categorization score, millennial generation employees who worked at start-up companies in D.I. Yogyakarta, DKI Jakarta and West Java have high organizational citizenship behavior. In addition, there were still millennial generation employees who worked at start-up companies in D.I. Yogyakarta, DKI Jakarta and West Java have categorized low organizational citizenship behavior which needs to be a concern for companies hence they do not experience a decline.

The result of research on start-up companies employees in Indonesia showed that the hypothesis which was there is a positive relationship between perceived organizational support and creative behavior through organizational citizenship behavior,was proven to be significant. In addition, it was also proven that there were significant results on the hypothesis regarding the direct relationship between perceived organizational support and creative behavior.

The hypothesis that showed a positive relationship between perceived organizational support and organizational citizenship behavior on creative behavior was significant. This result showed that the three variables have a significant correlation hence the conditions for using the mediator variable was met. 
The total effect involving the role of organizational citizenship behavior was greater than the number of direct effects of perceived organizational support on creative behavior without mediated organizational citizenship behavior. It means that perceived organizational support and organizational citizenship behavior were quite influential on increasing creative behavior.

Perceived Organizational Support and Creative Behavior through Organizational Citizenship Behavior Employees who believe in the perception of organizational support that they were supported by the organization at work can increase voluntary civic behavior, because of the underlying social exchange theory which was founded on trust and goodwill built between the two parties (Eisenberger et al., 1986; Rhoades \& Eisenberger, 2002; Yoon \& Suh, 2004). Employees who demonstrated organizational citizenship behavior will feel they are part of their organization and will share needed knowledge with their colleagues voluntarily. The influence of this social behavior will show the creative behavior of employees. This was stated by Perry-Smith and Shalley (2003) that interaction with other people accompanied by an exchange of ideas can increase the potential for employee creativity.

Jebeli and Etebarian (2015) explained that the high perception of employees towards organizational support can also increase organizational citizenship behavior of employees and vice versa. In other words, if the organization provides high support for employee creativity, then this can direct their attention in generating new ideas and ways of doing things to adapt and improve their work and results. Employees who receive more support from the company will be more responsible for their work, helping their colleagues and providing useful ideas.

\section{Perceived Organizational Support and Creative Behavior}

Perceived organizational support that employees have has a big role in increasing employee creativity because with this creativity organizational performance and productivity, it will increase as employees will feel motivated (Ibrahim et al., 20I5; Kahn, 1992). Oldham and Cummings (1996) stated that one form of organizational supports is the role of supervision that is able to provide support to its employees. Supervision that supports employees is argued to 
be able to increase employee creative achievement. However, if supervision is too controlling and limits the activities of employees in completing their tasks, it will lower employee creativity.

Other findings also add that organizational support and creativity were the extent to which an employee perceives these two aspects. If the organization is able to emphasize that creativity is a valuable thing for the organization, and is able to communicate these values then it forms a culture that strengthens the values of managed creativity management (lbrahim et al., 20I5; Choi, et al., 2010). This previous result was also consistent with the research conducted by Akgunduz, Alkan, and Gok (2018) which showed that perceived organizational support has a positive influence on employee creativity.

\section{Conclusion}

Organizational citizenship behavior has a function as a mediator between perceived organizational support on the creative behavior of employees of start-up companies in Indonesia. The higher the perceived organizational support owned by employees, it will increase the creative behavior of employees through organizational citizenship behavior which was also appeared higher and vice versa. In addition, perceived organizational support also has a direct effect on improving the creative behavior of start-up company employees. The higher perceived organizational support owned by employees, the higher creative behavior of employees and vice versa.

For companies, start-up companies are expected to be able to increase creative behavior through perceived organizational support and organizational citizenship behavior. Therefore, the form of organizational support provided to employees needs to be considered thus it can increase organizational citizenship behavior which has an impact on the high creative behavior of employees. For example, by providing promotions, salary increases, and best employee awards every week. Furthermore, by paying attention to and following up on employee complaints, as well as notifying when work is not done properly. Moreover, it can also be done 
by showing an attitude of great concern for employees towards the welfare of employees and being proud of the results of the work done by employees.

For future researchers, it is hoped that more research on reference sources will support research on this topic, or expand by considering other aspects that influence creative behavior as well as aspects and indicators related to perceived organizational support and organizational citizenship behavior. This research was only conducted on the millennial generation, hence further researchers can re-research with more than one generation and include more start-up companies. In addition, it is highly suggested to implement and use other methods e.g. qualitative method or experimental method.

\section{References}

Akgunduz, Y., Alkan, C., Gok, O. A. (2018). Perceived organizational support, employee creativity and proactive personality: the mediating effect of meaning of work. Journal of Hospitality and Toursim Management, 38, I05-II4.

Akturan, A. \& Cekmecelioglu, H. G. (2016). The effects of knowledge sharing and organizational citizenship behaviors on creative behaviors in educational institutions. Procedia - Social and Behavioral Sciences, 50, 235-242.

Ali, H. \& Purwandi, L. (20I7). Millennial nusantara. Jakarta: PT Gramedia Pustaka Utama.

Amabile, T. M. (1997). Motivating creativity in organizations: On doing what you love and loving what you do. California Management Review, 40(I).

Amabile, T. M. (1996). Creativity in context update to the social psychology of Creativity. Boulder, CO, US: Westview Press.

Amabile, T. M., Conti, R., Coon, H., Lazenby, J., \& Herron, M. (1996). Assessing the work environment for creativity. Academy of Management Journal, 39(5), I I 54-I I 84.

Biggs, R., Wetley, F.R. \& Carpenter. S.R. (2010). Navigating the back loop: Fostering social innovation and transformation in ecosystem management. Ecology and Society, I5(2), I26. 
Choi, S. Y., Lee, H. \&Yoo, Y. (2010). The impact of information technology and Transactive Memory System on Knowledge Sharing Application, and Team Performance: A field study. MIS Quaterly, 34(4), 855-870.

Clarke, T. \& Clegg, S. (2000). Management paradigms for the new millennium. International Journal of Management Reviews. 2 (I), 45-64.

Eggers, F., Lovelace, K. J., \& Kraft F. (2017). Fostering creativity through critical thinking: The case of business start-up simulations. Creativity and Innovation Management, I6(3), 266276.

Badan Pusat Statistik. (2017, November 3). Accesed on March 2I, 2018 from web https://www.bps.go.id/publication/20I7/II/03/5cdcfabd0f6fca476cb548e6/statistikpemuda-indonesia-2016.html

Dale Carnagie Indonesia. (2018, Januari 16). Accesed on March 21, 2018 from web https://www.dalecarnegie.id/sumberdaya/media/media-coverage/infografis-millenial-ogahterlibat-sepenuhnya-di-perusahaan/

de Geus, C. J.C., Ingrams, A., Tummers, L., \& Pandey, S.K. (2020). Organizational citizenship behavior in the public sector: A systematic literature review and future research agenda. Public Administration Review, 7, I-I2.

Eisenberger, R., Huntington, R., Hutchison, S., Sowa, D. (1986). Perceived organizational support. Journal of Applied Psychology, 7 I (3), 500-507.

Eisenberger, R., Stinglhamber, F., Vandenberghe, C., Sucharski, I. L., Rhoades, L. (2002).

Perceived supervisor support: Contributions to perceived organizational support and employee retention. Journal of Applied Psychology, 87(3), 565-573.

Eggers, F., Lovelace, K.J., \& Kraft, F. (2017). Fostering creativity through critical thinking: The case of buniness start-up stimulations. Journal of Creativity and Inovation Management, 26 (3), 266-276.

Ferreira, J., Coelho, A., \& Moutinho, L. (2020). Dynamic capabilities, creativity and innovation capability and their impact on competitive advantage and firm performance: The moderating role of entrepreneurial orientation. Technovation, 92, I-I8.

Ghosh, K. (2014). Developing organizational creativity and innovation: Toward a model of selfleadership, employee creativity climate and workplace innovative orientation. Management Research Review, 38 (I I), I I26-I I 48. 
Ghozali, I. (2016). Aplikasi analisis multivariate dengan program IBM SPSS 23, Edisi VIII. Semarang: Badan Penerbit Universitas Diponegoro.

ibrahim, h. i., isa, a., \& shahbudin, a. s. m. (2016). Organizational support and creativity: The role of developmental experiences as a moderator. Procedia Economics and Finance, 509-5 I4.

Jebeli, M. J. \& Etebarian, A. (20I5). Perceived organizational support and organizational citizenship behavior. MAGNT Research Report, 3(4).

Kahn, W. A. (1992). To be fully there: Psychological presence at work. Human Relations, 45.

Kljin, M. \&Tomic, W. (2010). A review of creativity within organizations from a psychological perspective. Journal of Management Development, 29(4), 323-343.

Lancaster, L. C., \& Stillman, D. (2003). When generation collide: who they are, why they clash. how to solve the generational puzzle at work. New York: Harper Collins.

Madjar, N., Oldham, G.R., \& Pratt, M.G. (2002). There's no place like home? The contributions of work and non work creativity support to employees' creativity performance. Academy of Management Journal, 45 (4), 757-767.

McLean, L. D. (2005). Organizations culture's influence on creativity and innovation: A review of the literature and implication for human resource development. Advances in Developing Human Resource, 7 (2), 226-246.

Myers, K.K., \& Sadaghiani, K. (20I0). Millennials in the workplace: A communication perspective on millennials' organization relationship and performance. Journal of Business Psychology, 25 (225-238).

Moghimi S. \& Subramaniam, I. D. (20/3). Employees' creative behavior: The role of organisational climate in Malaysian SMEs. International Journal of Business and Management, 8(5), 234-239.

Ocampo, L., Acedillo, V., Bacunador, A. M., Balo, C.C., Lagdameo, Y.J. \& Tupa, N.C. (20I7). A historical review of the development of organizational citizenship behavior (OCB) and its implication for the twenty-first century. Personnel Review, 47(4), 82I-862.

Oldham, G. R. \& Cummings, A. (1996). Employee creativity: Personal and contextual factors at work. The Academy of Management Journal, 39(3), 607-634.

Organ, D. W., Podsakoff, P. M., \& MacKenzie, S. B. (2006). Organizational citizenship behavior: it's nature, antecedents, and consequences. Sage Publications, Inc. Rhoades, L. \& Eisenberger, R. (2002). Perceived Organizational Support: A Review of the Literature. Journal of Applied Psychology, 87(4), 698-7I4. 
Perry-Smith, J. E., \& Shalley, C. E. (2003). The Social side of creativity: a Static and dynamic social network perspective. Academy of Management Review, 28, 89-106.

Rhoades, L. \& Eisenberger, R. (2002). Perceived organizational support: a Review of the literature. Journal of Applied Psychology, 87(4), 698-7I4.

Riaz, H. \& Hassan, A. (2019). Mediating role of organizational creativity between employee's intention in knowledge management process and organizational performance: Empirical study on pharmaceutical employees. Pakistan Journal of Commerce and Social Sciences, I3 (3), 635-655.

Rice, G. (2006). Individual values, organizational context and self perceptions of employee creativity: Evidence from Egyptian organizations. Journal of Business Research, 59(2), 233241.

Yoon, S. \& Suh, H. (2004). Ensuring IT consulting SERVQUAL and user satisfaction: A Modified Measurement Tool. Information System Frontier, 6(4), 34I-35I.

Yulianti, P. (20/4). Building organizational citizenship behavior with creative organizational climate support: a Conceptual framework in higher education. International Research Journals, 5(3), 98-106. 